\title{
Interceptação, pelo Serviço de Quarentena, de Vírus em Mudas Meristemáticas de Bananeiras Importadas
}

\author{
Vera Lúcia A. Marinho \& Maria de Fátima Batista \\ EMBRAPA Recursos Genéticos e Biotecnologia, Cx. Postal 02372, CEP 70770-900 Brasília, DF, Brasil, \\ e-mail: vmarinho@cenargen.embrapa.br
}

(Aceito para publicação em 08/07/2004)

Autor para correspondência: Vera Lúcia de A. Marinho

\begin{abstract}
Quarantine Service interception of virus in imported meristem cultures of banana

In 2003, banana (Musa sp.) producers located in the Northeast Region of Brazil imported a great number of micropropagated banana plantlets with the objective of enhancing production for exportation and internal consumption. Although it is an important activity for agribusiness, these importations can introduce and/or spread exotic and economically important pests to Brazil, causing serious damage to our agriculture. With the objective of minimizing the risk of virus introduction, representative samples from a group of 140,000 banana buds imported from Costa Rica were analyzed by ELISA tests at the Quarantine Laboratory of Embrapa Genetic Resources and Biotechnology (Cenargen). Banana bract mosaic virus, which is an exotic virus to Brazil and Banana streak virus were detected in the analyzed material. Although the acquisition of new genotypes is very important for the implementation of banana production in Brazil, it is shown here that the risk of introduction and dissemination of viruses associated with the material is real, and therefore, the need of phytosanitary measures to minimize those risks must be emphasized.
\end{abstract}

A introdução de germoplasma vegetal no Brasil é indispensável para o enriquecimento do patrimônio genético, disponibilizando novos genótipos que incrementam a agricultura nacional (Marinho et al. Série Documentos Embrapa, $\mathrm{N}^{\circ}$ 50:117. 2001). Embora seja uma atividade importante, essa prática pode introduzir pragas exóticas ou de importância econômica para o país. Nos últimos anos, a introdução de novos genótipos de banana (Musa sp.) tem sido intensificada, gerando preocupações para os órgãos de defesa fitossanitária. Dentre os vírus de bananeira exóticos para o Brasil, encontram-se o Banana bunchy top virus (BBTV), família Circoviridae, gênero Nanavirus, praga de quarentena A1 para o Brasil (MAPA, Instrução Normativa SDA N 38, 14 de outubro 1999), que ocorre em vários países da Ásia, África, Oceania e Havaí, transmitido de forma persistente pelo afídeo Pentalonia nigronervosa Coquerel, e o Banana bract mosaic virus (BBrMV), família Potyviridae, gênero Potyvirus, que, embora não ocorra no Brasil, não está regulamentado como praga de quarentena. O BBrMV é transmitido de forma não persistente por afídeos, infeta plantas da família Musaceae e está presente em vários países da Ásia e África. Ambos os vírus são transmitidos eficientemente por material de propagação vegetativa e causam severos danos à bananicultura (Thomas et al., Phytopathology 87:698-705. 1997). Em 2003, foram introduzidas, no Estado do Rio Grande do Norte, 140.000 mudas meristemáticas de bananeira 'Williams', distribuídas em quatro lotes, sendo o primeiro de 20.000 e os seguintes de 40.000 plântulas, provenientes da Costa Rica. Amostras representativas dos quatro lotes de plântulas importadas, $1 \%$ do total de mudas, foram enviadas ao Serviço de Quarentena da Embrapa Recursos Genéticos e
Biotecnologia (Cenargen), para análises fitossanitárias. As mudas foram testadas quanto à presença dos dois vírus exóticos ao Brasil e para o Cucumber mosaic virus (CMV), família Bromovirodae, gênero Cucumovirus e o Banana streak virus (BSV), família Caulimoviridae, gênero Badnavirus, já presentes no país. Foram realizados testes de ELISA, usando kits comerciais (AGDIA, USA), específicos para os quatro vírus em questão, segundo os procedimentos indicados pelo fornecedor. Os antígenos foram preparados triturando-se $1 \mathrm{~g}$ de tecido das plântulas (raiz, caule e folhas), em presença do tampão de extração (1:10 p/v) provido no kit. Os testes foram realizados com duas repetições para cada amostra, sendo utilizados controles positivos e negativos para cada vírus. No primeiro lote analisado foram detectados o BBrMV e o BSV. Todas as 20.000 mudas de bananeira foram incineradas, evitando assim a introdução dessa nova praga no Brasil. Nos três outros lotes não foi detectado o BBrMV, mas em todos eles foi constatada a presença do BSV. Esse resultado demonstra a vulnerabilidade da agricultura brasileira quanto à introdução de pragas associadas à importação de plantas. Esta constatação deixa em alerta os serviços de quarentena quanto à necessidade da utilização de técnicas cada vez mais sensíveis para detecção e identificação de vírus em bananeira, evitando, assim, a entrada e/ou disseminação de vírus no país. A adoção desta medida possibilita que novos genótipos a introdução de forma segura no Brasil, salvaguardando os sistemas agrícolas de perdas potenciais na produção.

AGRADECIMENTO: Os autores agradecem ao Dr. Paulo Sérgio Brioso, da UFRRJ, pela confirmação do diagnóstico do BBrMV e BSV utilizando métodos moleculares. 